\title{
MIÓD I POPIÓŁ. FIGURY PAMIĘCI
}

Dagmara Drewniak, Forgetful Recollections: Images of Central and Eastern Europe in Canadian Literature, Poznań: Wydawnictwo Naukowe UAM, 2014, 221 s. (rec. Anna Branach-Kallas).

Poniższy szkic rozpocząć należy od konstatacji natury ogólnej: literatura kanadyjska - mimo jej bogactwa, poświadczonego między innymi wielością polskich przekładów - jest $\mathrm{w}$ naszym piśmiennictwa niedostatecznie rozpoznana. Samo pojęcie literatury kanadyjskiej, wypracowane na jej rodzimym gruncie, jawi się jako niezwykle złożone, nastręczając jeszcze więcej trudności niż tak zwana literatura amerykańska (terminu tego używam w zwyczajowym sensie wąskim ${ }^{1}$ ).

Co bowiem mamy na myśli, mówiąc o literaturze amerykańskiej, czy też literaturze USA, powstającej w owym postulowanym przez badaczu ,tyglu kultur”? Czy należy założyć, iż pojęcie to odnosi się do wszystkich tekstów literackich, powstałych na terytorium tego kraju, bez względu na to, skąd pochodzą ich twórcy? Czy utwory pisane przez obywateli USA, pozostających przez większość swego życia na obczyźnie i jawnie manifestujących przynależność do nowej kultury, również należy uznać za przykłady literatury Stanów Zjednoczonych? Czy twórczość takich pisarzy jak Vladimir Nabokov, W. H. Auden, Henry James czy T. S. Eliot rozpatrywać należy w obrębie tego samego pojęcia? Tego typu pytania można, rzecz jasna, mnożyć, dochodząc wreszcie do fundamentalnej kwestii języka, w którym owe teksty powstają — kwestii tylko na pozór prostej. Jeśli bowiem literatura amerykańska obejmuje jedynie utwory w języku angielskim, cóż począć np. z poliglotycznymi lub wręcz hiszpańskojęzycznymi tekstami pisarzy, wywodzących się ze społeczności Chicano, tj. ludności meksykańskiej, zamieszkującej głównie pogranicze USA i Meksyku?

Jak widać, trudno o precyzyjną definicję literatury amerykańskiej. Zakreślenie ram literatury kanadyjskiej jest jednak przedsięwzięciem daleko trudniejszym. Już u samych podstaw kanadyjskości mamy bowiem do czynienia $\mathrm{z}$ istnym kulturowym pęknięciem (o ile przyjmiemy optykę pesymistyczną) lub z napiętym współistnieniem (jeśli spojrzymy nieco bardziej optymistycznie) dwóch obszarów kulturowych, mocno okopanych w języku, która to sytuacja jest wynikiem nie tak znów odległych kolonialnych praktyk i sporów między imperiami. W Kanadzie mocno zakorzeniona jest koncepcja „dwóch samotności” (two solitudes), wywiedziona z tytułu powieści Hugh MacLennana z 1945 r. i odnosząca się właśnie do owego podziału na użytkowników języka angielskiego (,anglofonów”) oraz tych, którzy posługują się francuszczyzną (,frankofonów”). W świecie, zwłaszcza w wyniku spektakularnego zwycięstwa kana-

\footnotetext{
${ }^{1}$ Kieruję się w tym względzie przede wszystkim decyzją Agnieszki Salskiej, redaktorki $\mathrm{Hi}$ storii literatury amerykańskiej $X X$ w., tekstu niewątpliwie kluczowego dla polskich badań amerykanistycznych, gdzie przymiotnik ten oznaczać ma „odnosząc[y] się do dzisiejszych Stanów Zjednoczonych Ameryki Północnej”; Historia literatury amerykańskiej XX w., red. A. Salska, t. 1, Kraków 2004, s. 9.
} 
dyjskiej Partii Liberalnej nad konserwatystami pod koniec 2015 r., zdaje się dominować obraz Kanady jako kraju wiodącego prym w niwelowaniu napięć, jakie z natury swej rodzi społeczeństwo wielokulturowe. Warto jednak pamiętać o tym, iż w ostatnim czterdziestoleciu Quebec dwukrotnie usiłowano oderwać od Kanady na drodze referendum (za drugim razem odnosząc nieomal sukces), zaś w 1970, w czasie tzw. kryzysu październikowego, państwo kanadyjskie było o krok od wojny domowej.

Już z racji wspólistnienia owych „dwóch samotności,” literatura Kanady — kraju Nowego Świata, ufundowanego tak jak Stany Zjednoczone na wkładzie imigranckim jawi się jako zjawisko ze wszech miar niejednolite, a przecież należy wziąć również pod uwagę kulturotwórczy udział ludności rdzennej. Jednak Kanada już od co najmniej kilkudziesięciu lat nie może być traktowana li tylko jako arena, na której ścierają się w różnych konfiguracjach pierwiastki anglofońskie, frankofońskie i autochtoniczne; jest to wszak, przynajmniej od czasu rządów Pierre’a Trudeau, państwo, w którego oficjalną definicję wpisana jest wielokulturowość (multiculturalism) - kraj, który sam siebie postrzega jako mozaikę kultur². Bez przywołania pojęć takich jak wielokulturowość czy postulowana przez Marie Vautier odważniejsza i dynamiczniejsza „transkulturowość” (transculturalism), nie sposób właściwie mówić o społeczeństwie dzisiejszej Kanady.

Stan ów bez wątpienia znajduje odzwierciedlenie w kulturze tego kraju, a więc i w uprawianej w nim twórczości literackiej. Nie bez powodu wspomina się więc w ostatnich dziesięcioleciach również „inne samotności” (other solitudes) lub też „trzecie samotności" (third solitudes): chodzi tu oczywiście przede wszystkim o inne obszary kulturowe, językowe i etniczne ${ }^{3}$. Choć obraz literatury kanadyjskiej bez wątpienia zyskuje dzięki takiemu poszerzeniu, nie należy zapominać o dość melancholijnym tonie samych terminów. I mimo że w kanadyjskim dyskursie publicznym właściwie nie wypada już wspominać o „dwóch samotnościach”, na których ufundowano w obrębie niegdysiejszych kolonii nowoczesną państwowość ${ }^{4}$, to ów termin — opatrzony takim przymiotnikiem jak ,inny” — zdaje się najlepiej opisywać kondycję pisarstwa uprawianego w obrębie niektórych, mniej „,modnych” grup etnicznych czy kulturowych. To właśnie takim samotnościom przygląda się w swej książce z należytą uwagą Dagmara Drewniak.

Zgodnie z podtytułem książki (w polskiej wersji: Obrazy Europy Środkowo-Wschodniej w literaturze kanadyjskiej), Autorka poświęciła swoją rozprawę tekstom, które na szereg sposobów nawiązują dialog między kanadyjskim Nowym Światem a starym kontynentem. Nie chodzi tu jednak o tę Europę, z której wykiełkowały

${ }^{2} \mathrm{~W}$ idealistycznej koncepcji mozaiki często upatruje się różnicy między kanadyjskim a amerykańskim (sensu stricto) postrzeganiem współistnienia kultur. Wedle tej koncepcji, Kanada nie przypomina tygla, w którym wielość przechodzi w jedność, na wzór amerykańskiej formuły e pluribus unum; w kanadyjskim społeczeństwie wielokulturowym poszczególne komponenty mają koegzystować, zachowując swą odrębność, jednocześnie zaś tworząc pewną harmonijną całość; Por.: M. Abramowicz, Kanadyjska mozaika kultur, Więź 2011 nr 4 (630).

${ }^{3}$ Biorąc pod uwagę zakres tematyczny książki Dagmary Drewniak, warto wymienić tu zwłaszcza zbiór esejów Michaela Greensteina pod tytułem Third Solitudes, poświęcony literaturze żydowskiej w Kanadzie. Greenstein zajął się zarówno tekstami w języku angielskim, jak i w języku francuskim, choć - co ciekawe - nie utworami powstałymi w jidysz; M. Greenstein, Third Solitudes: Tradition and Discontinuity in Jewish-Canadian Literature, Montreal 1989.

${ }^{4}$ W 2005 r. Michaëlle Jean, pełniąca podówczas funkcję Gubernatora Generalnego Kanady, stwierdziła optymistycznie w swym przemówieniu inauguracyjnym, że „epoka dwóch samotności dobiegła końca"; T. Weber, Time of two solitudes has passed: Jean, The Globe and Mail, 27.09.2005 http://www.theglobeandmail.com/news/national/time-of-two-solitudes-has-passedjean/article20426310/ 
w XVIII i XIX w. kanadyjskie struktury państwowe, ale o tę, która głównie z racji wojen i innych konfliktów zeszłego stulecia zasiliła Kanadę rzeszą imigrantów. Dzieje owych migracji przedstawia Autorka dość szczegółowo w pierwszym rozdziale, który znamionuje wyraźny rys teoretyczno-historyczny. Nie idzie więc o takie względnie stabilne państwowości jak Wielka Brytania czy Francja, lecz o byty często widmowe, państwa-niepaństwa, które znikały z map, by po wielu latach pojawić się znów, często w radykalnie zmienionym (okaleczonym lub obrzmiałym) kształcie. Same pojęcia „Europy Środkowej” czy „Europy Wschodniej” jawią się zatem jako niedookreślone i niemal domagają się zbawczego cudzysłowu; nic więc dziwnego, iż wprowadzając je na początku swego wywodu, Autorka przywołuje z pozoru tylko odległe pojęcie geografii wyobrażonej (imagined geography) Edwarda Saida (s. 11), archeologiczną koncepcję przestrzeni środkowoeuropejskiej, przedstawioną niedawno przez słoweńską badaczkę, Simonę Škrabec (s. 12), czy też stwierdzenie Anny Porter, że Europę Środkową należy traktować raczej jako „stan umysłu” (a state of mind) niż jako przestrzeń ściśle geograficzną (s. 61).

Mowa tu zatem głównie o obszarach takich jak Polska czy Ukraina, a incydentalnie również Rosja, Litwa lub Czechy. W obrębie owej mgławicowości geograficznej i tożsamościowej, obejmującej tak złożone pojęcia jak „polskość” czy „ukraińskość” właśnie, pojawia się pojęcie jeszcze bardziej zawikłane i niejasne, a mianowicie „żydowskość". W trzech rozdziałach analitycznych Autorka zajmuje się bowiem opublikowanymi na przełomie XX i XXI wieku tekstami sześciorga kanadyjskich autorów, piszących po angielsku, urodzonych między rokiem 1940 a 1963, których to korzenie sięgają wspomnianych wyżej terenów. Korzenie te są różnorakie: polskie (Eva Stachniak), ukraińsko-polskie (Janice Kulyk-Keefer), polsko-żydowskie (Lisa Appignanesi, Anne Michaels, Norman Ravvin), czy wreszcie rosyjsko-polsko-żydowskie (Irena F. Karafilly). W parze z owym geograficzno-tożsamościowym splątaniem idzie nie tylko zróżnicowanie obieranych form literackich, ale i zaskakująca porowatość tychże: powieści okazują się przesączone materiałem autobiograficznym i faktograficzną precyzją, zaś teksty wspomnieniowe manifestują swą częściową fikcjonalność.

Również status sześciorga omówionych pisarzy w obrębie rodzimej (tj. kanadyjskiej) kultury jest dalece niejednorodny. Znaleźli się tu twórcy poczytni za oceanem, jak Anne Michaels, znana i u nas z powieści Fugitive Pieces (Płomyki pamięci, przeł. Bogumiła Malarecka), czy Eva Stachniak, której powieść The Winter Palace (Katarzyna Wielka. Gra o władzę, przeł. Ewa Rajewska) święci obecnie międzynarodowe triumfy czytelnicze. Również tekst omawiany przez Drewniak, Necessary Lies, choć mniej znany w Nowym Świecie, zaistniał u nas w przekładzie Katarzyny Boguckiej-Krenz jako Konieczne kłamstwa; podobnie rzecz ma się z memuarem Lisy Appignanesi pt. Losing the Dead. A Family Memoir, przełożonym przez Michała Ronikiera jako Żegnajac umartych. Pamiętnik rodzinny.

Przynajmniej część omówionych przez Drewniak twórców śmiało jednak nazwać można niszowymi, a nawet postawić równie śmiałą tezę, iż na ich niewielką popularność (tak wśród czytelników, jak i krytyków) bezpośredni wpływ ma swoiste powikłanie ich historii rodzinnych oraz to, że wiążą się one $\mathrm{z}$ terenami tak mgliście identyfikowanymi przez czytelnika północnoamerykańskiego jak Ziemie Odzyskane, Kresy Wschodnie czy (przynajmniej do niedawna) samo pogranicze polsko-ukraińskie.

W książce swej Dagmara Drewniak śledzi zatem próby zadzierzgnięcia nici między kanadyjskimi środowiskami imigranckimi a na w poły mitycznym, tyleż demonizowanym, co idealizowanym światem Europy „Środkowo-Wschodniej”. Na spotkanie samotności diaspor w Kanadzie wychodzi tu więc samotność uciemiężonych narodów, 
marginalizowanych i prześladowanych mniejszości, a niemal wszędzie zalega dalekosiężny cień Zagłady. Podtytuł książki może jednak być dość mylący, nie tylko ze względu na sugerowany przynajmniej pośrednio zakres (a więc literaturę kanadyjską in toto), ale i dlatego, że czytelnik mógłby spodziewać się rozprawy traktującej wyłącznie o (wąsko rozumianej) literaturze pięknej. Tymczasem obok czterech omówionych przez Drewniak powieści - tj. Necessary Lies Evy Stachniak (2000), The Winter Vault Anne Michaels (2009), The Memory Man Lisy Appignanesi (2005) oraz Café des Westens Normana Ravvina (1991) — pojawiają się trzy teksty wspomnieniowe, już swymi podtytułami sygnalizujące gatunkową przynależność: Losing the Dead. A Family Memoir Lisy Appignanesi (1999), Honey and Ashes: A Story of Family Janice Kulyk Keefer (1998) oraz The Stranger in the Plumed Hat: A Memoir (2000) Ireny F. Karafilly. Z owej decyzji, która może zrazu wydać się dyskusyjna, Autorka thumaczy się sprawnie już we wstępie (s. 31), motywując swój wybór wspomnianą powyżej porowatością takich kategorii jak powieść czy tekst wspomnieniowy w obliczu badań historiograficznych spod znaku Haydena White'a (odniesienia do Realizmu figuralnego w literaturze świadectwa pojawiają się w książce bardzo wcześnie).

Właśnie ze względu na wspominany już splot „samotności” wydaje się niefortunne, że książka Dagmary Drewniak ukazała się po angielsku. Choć decyzji tej bronić można oczywiście dążeniem do zwiększenia konkurencyjności polskiej nauki na światowych rynkach akademickich, odnoszę wrażenie, że studium dotykające tak głęboko zagmatwań tożsamościowych i geograficznych — nam tak dobrze znanych, lecz zupełnie nieprzejrzystych dla czytelnika północnoamerykańskiego — powinno strategie pisarskie autorów z kanadyjskich kręgów imigranckich przedstawić polskiemu środowisku naukowemu w jego ojczystym języku. Taki nurt badawczy sygnalizowali w ostatnich latach m.in. Mirosława Buchholtz w książce Polska w Kanadzie, Kanada w Polsce (2008), Bożena Szałasta-Rogowska np. w zbiorze Literatura polska w Kanadzie. Studia i szkice (2010) czy Eugenia Sojka w ważnym eseju pt. Twórczość polskiej diaspory w Kanadzie a kanadyjski dyskurs literacki. Prolegomena do współczesnych badań (2010); niedawno zaś świetny przykład dała naszym kanadystom Anna Branach-Kallas, publikując po polsku cenny zbiór esejów pod swoją redakcją (Niuanse wyobcowania. Diaspora i tematyka polska w Kanadzie, Torun 2014), a także własną, szerzej zakrojoną rozprawę pt. „,Uraz przetrwania”. Trauma i polemika z mitem pierwszej wojny światowej w powieści kanadyjskiej (Toruń 2014).

Sądzę, że praca Drewniak świetnie wpisałaby się w zarysowany powyżej nurt. W obecnym zaś kształcie tekst wchodzi raczej w dialog z takimi pozycjami, opublikowanymi na rynku kanadyjskim, jak wspomniana już książka Michaela Greensteina pt. Third Solitudes: Tradition and Discontinuity in Jewish-Canadian Literature (Montreal 1989), A House of Words. Jewish Writing, Identity and Memory Normana Ravvina (Montreal 1997) ${ }^{5}$, Leaving Shadows: Literature in English by Canada's Ukrainians Lisy Grekul (Edmonton 2005) czy At Odds in the World: Essays on Jewish Canadian Women Writers autorstwa Ruth Panofsky (Toronto 2008). Z drugiej strony, pracę Drewniak należy również rozpatrywać w odniesieniu do rozlicznych publikacji przedstawiających szersze spojrzenie na fenomen literatury etnicznej i diasporycznej, jak np. Scandalous Bodies: Diasporic Literature in English Canada autorstwa Smaro

\footnotetext{
${ }^{5}$ Nadmienić trzeba, iż Norman Ravvin występuje w tekście Drewniak w roli podwójnej, tj. jako autor jednego z omawianych tekstów prozatorskich (powieści Café des Westens) oraz wymienionych tutaj rozpraw krytycznoliterackich, poświęconych zwłaszcza literaturze żydowskiej w Ameryce Północnej.
} 
Kamboureli (Oxford 2000) czy Borrowed Tongues. Life Writing, Migration, and Translation Evy C. Karpinsky (Waterloo, Ontario 2012).

Kluczowym zagadnieniem staje się tu oczywiście pamięć. Szkoda, że polskie brzmienie głównej części tytułu (Przypominajac zapomniane) nie oddaje w pełni paradoksu, zawartego w oryginalnej wersji, tj. Forgetful Recollections, która zdaje się sprzęgać w niewygodną, acz ekscytującą całość przeciwne wektory pamiętania i zapominania, czerpiąc swą siłę z antynomii. Istotnie, napięcie to leży u podstaw całego przeprowadzonego w książce wywodu, co znajduje wyraz w doborze wykorzystanych przez autorkę narzędzi teoretycznych. Zapominanie jest tu rozumiane nie tylko jako proces naturalny, nieuświadomiony i jednostkowy, ale - idąc tropem Paula Ricoeura - jako ars oblivionis, sztuka zapomnienia, w której wprawiać się mogą nie tylko poszczególne jednostki, ale i całe wspólnoty. Sama pamięć, zarówno w ujęciu jednostkowym jak i wspólnotowym, jest również problematyzowana, właśnie przez odwołania do historiografii White'a oraz klasycznego już, hybrydowego tekstu Michaela Ondaatje, Running in the Family. To wszystko jasne sygnały, iż osią książki Drewniak będą napięcia między historią a pamięcią, narracją oficjalną a prywatną, doświadczeniem zbiorowym a indywidualnym.

Bodaj najważniejszym jednak z narzędzi krytyczno-teoretycznych, którymi posługuje się w swej książce Drewniak, jest koncepcja postpamięci (postmemory), ukuta przez Marianne Hirsch na potrzeby opisania wspomnień dziedziczonych przez potomków tych, którzy ocaleli z Zagłady; wspomnienia takie stają się według Hirsch dotkliwym elementem własnej tożsamości potomnych. Przywołanie Hirschowskiej postpamięci nie powinno oczywiście dziwić w przypadku perspektywy badawczej, zwróconej ku literackim oraz pozaliterackim przedstawieniom ciężaru, jakim dla dzieci ocalałych jest przeszłość, często całkowicie niejasna i pełna niepokojących luk. Oryginalność pomysłu Drewniak polega jednak na tym, iż zdecydowała się ona rozszerzyć sens pojęcia postpamięci tak, by objąć nim również psychologiczne konsekwencje dotykające potomków tych, którzy zostali wysiedleni lub też emigrowali z innych przyczyn. Jak zauważa Autorka Forgetful Recollections (s. 28-29), sama Hirsch wycofała się kilka lat temu z twierdzeń, że termin ten powinien być stosowany wyłącznie do opisu doświadczeń poholokaustowych; jako przykłady okoliczności uzasadniających jego użycie zaproponowała wówczas bolesną schedę dyktatur południowoamerykańskich, konfliktów w Bośni, Rwandzie i Darfurze, zdarzeń 11 września 2001 w USA, a także sporu izraelsko-palestyńskiego. Można jednak zastanawiać się, czy Hirsch tym samym rzeczywiście usankcjonowała tak szerokie rozumienie pojęcia, jakie proponuje w swoim wywodzie Drewniak; wydaje się, że choć Szoa istotnie traci tu swój unikalny charakter, według twórczyni pojęcia esencją doświadczenia postpamięci ma wciąż być trauma związana ze zmasowaną przemocą, systemowym złem.

Kolejnym wyborem krytycznoliterackim, dającym analogiczne możliwości, ale i mogącym rodzić podobne pytania, jest posłużenie się wypracowaną przez Pierre'a Norę wielowymiarową koncepcją miejsc pamięci (lieux de mémoire), opisującą umiejscowienie szczątkowej pamięci nie tylko w przestrzeniach geograficznych, ale i w budynkach, archiwach, przedmiotach, dziełach sztuki czy nawet ludziach. Tak też rozumie je w swojej książce Drewniak: w tym wypadku lieux de mémoire to przede wszystkim ojczyste ziemie, odmienione domy i kartoteki pełne dokumentów, które kryją być może klucz do zagadek, trapiących potomków tych, którzy musieli te tereny z różnych przyczyn opuścić.

Zrozumiałym gestem Autorki jest również skorzystanie z bogatej teorii traumy (m.in. z dorobku Cathy Caruth, Dori Laub czy Shoshany Felman) dla opisania specy- 
ficznej relacji pokolenia ocalałych z ich własną przeszłością — szczególnie zaś ich milczenia, które stanowi swoiste brzemię dla potomnych ${ }^{6}$. Milczenie owo, niekiedy paradoksalnie przełamane $\mathrm{w}$ późnej fazie życia gwałtownym, patologicznym słowotokiem, będącym wynikiem choroby Alzheimera (jak w przypadkach opisanych przez Lisę Appignanesi i Irene Karafilly), interpretowane jest właśnie jako objaw traumy.

Autorka Forgetful Recollections proponuje zatem wielopłaszczyznowe, złożone spojrzenie na problem pamięci oraz na sposoby jej przedstawiania w literaturze tworzonej przez potomków ocalałych, wysiedlonych i imigrantów. Pamięć, często niejasna i obarczona milczeniem, zamieszkująca w ludziach, ale i w miejscach i przedmiotach, jest tu dziedziczona i przedzierzga się w postpamięć, która z kolei staje się dla kolejnych pokoleń brzemieniem niemal ponad siły. Autorka często korzysta przy tym (być może nie zawsze w sposób w pełni usystematyzowany) z metaforyki choroby zakaźnej; raz po raz w kontekście owej międzypokoleniowej wymiany, w której żadna ze stron nie uczestniczy z własnej woli, pojawia się słowo infect (,zarazić”, „zainfekować” — np. s. 72, 202). Zarażeni tym swoistym wirusem odczuwają przymus, by udać się - fizycznie lub tylko w obrębie sfery mentalnej - do miejsc pamięci, zwanych tu zbiorowo „Starymi Miejscami” (Old Places), na wzór ukraińskiej wsi Staromiejszczyzna, z której pochodzi rodzina Kulyk Keefer (s. 85). Terminem tym objęte zostają miejscowości tak różne jak Mława, Wrocław / Breslau czy Łódź. Przestrzenie te jako jedyne zdają się mieć moc uleczającą. Jednak to, co objawia się tym duchowym poszukiwaczom, okazuje się zaledwie „powidokiem” (after/image, s. 157), fantomem miejsc utkanych z cudzych wspomnień, pozbawionym owej uzdrawiającej mocy, zdolnej scalić pęknięty świat.

Choć Autorka określa te wyprawy jako „odyseuszowe” (Odyssean quest, s. 29), na myśl ciśnie się raczej inny, dalece bardziej tragiczny mit grecki: ten mianowicie, który opisuje zstąpienie Orfeusza do piekielnych czeluści oraz owo brzemienne w skutkach spojrzenie wstecz, ku ukochanej, którą heros ma za chwilę na zawsze utracić. W omawianych tekstach jednak ów metaforyczny gest (spojrzenia wstecz) wykonywany jest niejako w czyimś imieniu; w czyimś imieniu również dochodzi do ponownej, tym razem chyba nieodwracalnej utraty. By sprzęgnąc mit o Orfeuszu z tematem wojny, wysiedlenia i Zagłady, przywołać można by w tym miejscu Benjaminowski obraz Anioła Historii, który „,[z]wrócił oblicze ku przeszłości”, pragnąc „zbudzić umarłych i złączyć to, co rozbite", lecz jest wciąż pchany do przodu przez wiejący „od raju [...] wicher"

Jeden z omawianych przez Drewniak prozaików, Norman Ravvin, cytując Lucy Lippard, nazywa takich poszukujących „tragicznym turystami” (s. 72). Można odnieść wrażenie, iż są oni skazani są na to, by w imieniu przodków lub też przedstawicieli swej wspólnoty odwiedzać miejsca pamięci, których paradoksalna natura — zaznaczona właściwie już przez Norę czy Halbwachsa - polega na tym, że nie przechowują tego, co je uprzednio wypełniało i że to właśnie owa nieobecność dziś nadaje im szczególne znaczenie. Dlatego też teksty, omawiane przez Drewniak, nie przynoszą łatwych, uwznioślających objawień, które pozwolą pozszywać to, co rozdarte, ponownie związać nić przerwaną przez Zagładę, wypędzenie czy emigrację odbytą w mniej dramatycznych warunkach — bezboleśnie scalić rozdzieloną myślnikami tożsamość.

Biorąc pod uwagę piękny tytuł książki Janice Kulyk Keefer, Honey and Ashes (miód i popioły), a także szereg innych zawartych w niej i cytowanych przez Drewniak

\footnotetext{
${ }^{6} \mathrm{Na}$ gruncie najnowszej literatury polskiej zjawiska tego dotyka w sposób mistrzowski proza Magdaleny Tulli, zwłaszcza w takich wymykających się precyzyjnej klasyfikacji, głęboko osobistych tekstach jak Wloskie szpilki czy Szum.

${ }^{7}$ W. Benjamin, O pojęciu historii, przeł. K. Krzemieniowa, [w:] tegoż, Aniol historii. Eseje, szkice, fragmenty, oprac. H. Orłowski, Poznań 1996, s. 418.
} 
poetyckich sprzęgnięć (np. poison and ointment, czyli „trucizna i balsam”, s. 83, 92), o pamięci myśleć trzeba tu być może w kategoriach derridiańskiego farmakonu. Szkoda więc, że pojęcie to w Forgetful Recollections nie pada, ponieważ zdaje się ono zawierać w sobie wszystkie napięcia, które Autorkę interesują: te między pamięcią żywą i sztuczną (zapisaną), między mową a milczeniem, między trucizną a lekiem ${ }^{8}$. Sama metafora popiołów, pojawiająca się po wielokroć w odniesieniu do tekstów poholokaustowych, również prosi się o derridiańskie odczytanie: wszak popiół to „to, co pozostaje, nie pozostawiając śladu. [...] popioły muszą zawsze pozostawać poza zasięgiem topografii; [...] są rozproszone, są wszędzie i nigdzie, są tu i tam"9. Skądinąd, należy zauważyć, iż Derrida pojawia się w pracy przy innej okazji, mianowicie z racji wspomnianej mimochodem koncepcji otobiographies.

Choć Drewniak właściwie nie odnosi się wprost do przebijającej niejako spod powierzchni jej tekstu metaforyki choroby czy też infekcji, zaznacza w zakończeniu wspominając tekst Cynthii Sugars i jej figurę „(wy)dziedziczenia” (/dis/inheriting) w kontekście tożsamościowym - iż jest świadoma niebezpieczeństw, jakie nieść może ze sobą obsesja genealogiczna (s. 202). Mimo że wielu omawianym tekstom przyświeca chęć ustalenia i rozjaśnienia przeszłości, w całej książce Autorka zdaje się stawać w obronie tożsamości pluralistycznej i nieustalonej; chyba najlepiej ilustruje tę tendencję przytoczony na s. 99 cytat z Lindy Hutcheon: [m]y postmodern soul feels happier with plurality [„moja ponowoczesna dusza lepiej czuje się w wielości” — przekład mój, $\mathrm{KM}^{10}$ ]. Gdybyśmy chcieli zamknąć wnioski płynące z lektury książki Dagmary Drewniak w jednej, zgrabnej frazie, posłużyć temu mógłby z powodzeniem przytoczony przez Autorkę na s. 16 cytat z Honey and Ashes Janice Kulyk Keefer: [p]erhaps home is only this: inhabiting uncertainty [,,[n]iewykluczone, że być u siebie oznacza właśnie to: mieszkać w niepewności” — przekład mój, KM].

Nie wątpię w to, że Forgetful Recollections jest książką potrzebną i pod wieloma względami pionierską; w ujawnianym co rusz zamiłowaniu do geograficznej złożoności, sama staje się ona mapą obszernego terytorium kultury, które ani w Kanadzie, ani w Polsce nie zostało dotąd dostatecznie opisane. Szkoda jednak, że oryginalności analiz oraz odwadze krytycznej, której wymaga odczywywanie tekstów niszowych (a której Autorce nie brakuje) nie towarzyszy językowa precyzja. Wywód jest w części dość niestarannie zredagowany, jakby pospieszny i miejscami niedbały, co nieuchronnie rzutuje na odbiór przeprowadzonej przez Dagmarę Drewniak bardzo ciekawej i świeżej argumentacji.

Krzysztof Majer (Uniwersytet Łódzki)

\footnotetext{
${ }^{8}$ Por.: J. Derrida, Farmakon, [w:] tegoż, Pismo filozofii, przeł. B. Banasiak, Kraków 1993.

${ }^{9}$ T. Rachwał, T. Sławek, Maszyna do pisania. O dekonstruktywistycznej teorii literatury Jacquesa Derridy, Warszawa 1992, s. 217.

${ }^{10}$ L. Hutcheon, Critical Perspectives on Writing Ethnicity in Canada, [w:] Tricks with the Glass. Writing Ethnicity in Canada, red. R. Davis i R. Baena, Amsterdam 2000, s. 289 (cyt w: D. Drewniak, Forgetful).
} 